\title{
The phytoextraction potential of selected vegetable plants from soil amended with oil palm decanter cake
}

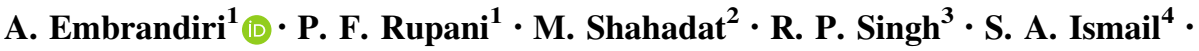 \\ M. H. Ibrahim ${ }^{1}$ M. O. Abd. Kadir ${ }^{1}$
}

Received: 1 September 2016/Accepted: 26 December 2016/Published online: 28 January 2017

(C) The Author(s) 2017. This article is published with open access at Springerlink.com

\begin{abstract}
Purpose The investigation of the phytoextraction potential of three vegetable plants grown in soils amended with decanter cake.

Method Pot experiments were conducted to investigate the response of decanter cake composition on the phytoextraction of metals $(\mathrm{Mg}, \mathrm{Zn}, \mathrm{Ni}$ and $\mathrm{Cu}$ ) by lady's finger, tomato and brinjal plants. The phytoextraction properties of these plants were determined by calculating the bioconcentration and translocation factors at different decanter cake amendments (10, 20 and 30\%).

Results Results indicated that in all three plants, there was no transfer of excess metal ions from the control soil or
\end{abstract}

A. Embrandiri

ashanty66@gmail.com

M. Shahadat

mdshahadat93@gmail.com

R. P. Singh

rajeevprataps@gmail.com

S. A. Ismail

sultanismail@gmail.com

M. H. Ibrahim

mhakimi@usm.my

M. O. Abd. Kadir

akomar@usm.my

1 Environment Division, School of Industrial Technology, Universiti Sains Malaysia, 11800 Pulau Pinang, Malaysia

2 Department of Biochemical Engineering and Biotechnology, Indian Institute of Technology, IIT Delhi, New Delhi 110016, India

3 Institute of Environment and Sustainable Development, Banaras Hindu University, Varanasi 221005, India

4 Eco-Science Research Foundation, Chennai 600041, India amendments to the fruit portion as evidenced by bioconcentration factor (BCF). In addition, substantial amount of the metals was found to be accumulated in the roots and shoots, which depicts the phytoextraction ability of these vegetable plants. The translocation factors (TF) of the three plants were found to be higher than control plants. The accumulation of metal ions did not exceed the permissible standards for vegetables thus rendering the fruits safe for human consumption.

Conclusion On the basis of significant findings, lady's finger, tomato and brinjal plants were not found to be suitable for phytoextraction of metals as both $\mathrm{BCF}$ and TF were not greater than 1 .

Keywords Decanter cake - Bioconcentration factor . Translocation factor - Phytoextraction - Palm waste . Lady's finger $\cdot$ Tomato $\cdot$ Brinjal

\section{Introduction}

The unprecedented rise in land use area for oil palm plantations in Malaysia and other palm-producing nations in the world have led to the immense quantities of wastes generated annually (Liew et al. 2015). This has lead to a big nuisance with regards to ground water pollution, infestation by rodents, spread of disease and, not to mention, the obvious odour issues. Various methods of re-utilizing the residues of the palm oil production process have been reported by a number of researchers. Almost all of the wastes have found use in one way or the other in different industries. However, with the exception of Embrandiri et al. (2012, 2013, 2016), Haron and Mohammed (2008), Razak et al. (2012), Gafar et al. (2013) and Adam et al. (2014) there is insufficient literature to show the utilization of 
Table 1 Analysis of soil, fresh decanter cake and mixtures (mean \pm SD)

\begin{tabular}{|c|c|c|c|c|c|}
\hline Parameter & Unamended soil (0\% DC) & $10 \% \mathrm{DC}$ & $20 \% \mathrm{DC}$ & $30 \% \mathrm{DC}$ & $100 \% \mathrm{DC}$ \\
\hline $\mathrm{pH}$ & $7.93^{\mathrm{a}} \pm 0.03$ & $6.81^{b} \pm 0.06$ & $6.71^{\mathrm{b}} \pm 0.02$ & $6.64^{\mathrm{b}} \pm 0.02$ & $4.40^{\mathrm{c}} \pm 0.01$ \\
\hline $\mathrm{EC}\left(\mathrm{mScm}^{-1}\right)$ & $1.43^{\mathrm{b}} \pm 0.02$ & $1.67^{\mathrm{b}} \pm 0.06$ & $2.72^{\mathrm{a}} \pm 0.03$ & $2.87^{\mathrm{a}} \pm 0.02$ & $2.96^{\mathrm{a}} \pm 0.02$ \\
\hline $\mathrm{Cd}\left(\mathrm{mg} \mathrm{g}^{-1}\right)$ & $0.13^{\mathrm{a}} \pm 0.02$ & $0.11^{\mathrm{a}} \pm 0.01$ & $0.10^{\mathrm{a}} \pm 0.01$ & $0.08^{\mathrm{a}} \pm 0.01$ & $0.05^{\mathrm{a}} \pm 0.01$ \\
\hline $\mathrm{Pb}\left(\mathrm{mg} \mathrm{g}^{-1}\right)$ & $0.77^{\mathrm{a}} \pm 0.11$ & $0.67^{\mathrm{b}} \pm 0.03$ & $0.63^{b} \pm 0.04$ & $0.60^{\mathrm{b}} \pm 0.01$ & $0.56^{\mathrm{c}} \pm 0.03$ \\
\hline $\mathrm{Ni}\left(\mathrm{mg} \mathrm{g}^{-1}\right)$ & $0.77^{\mathrm{a}} \pm 0.01$ & $0.73^{\mathrm{a}} \pm 0.02$ & $0.66^{\mathrm{ab}}+0.03$ & $0.65^{\mathrm{ab}} \pm 0.01$ & $0.63^{\mathrm{ab}} \pm 0.02$ \\
\hline $\mathrm{Cu}\left(\mathrm{mg} \mathrm{g}^{-1}\right)$ & $0.09^{\mathrm{b}} \pm 0.02$ & $0.15^{\mathrm{b}} \pm 0.02$ & $0.18^{\mathrm{b}} \pm 0.04$ & $0.30^{\mathrm{b}} \pm 0.02$ & $0.81^{\mathrm{a}} \pm 0.04$ \\
\hline $\mathrm{Mg}\left(\mathrm{mg} \mathrm{g}^{-1}\right)$ & $0.001^{\mathrm{b}} \pm 0.01$ & $0.003^{\mathrm{b}} \pm 0.02$ & $0.004^{\mathrm{b}} \pm 0.01$ & $0.005^{\mathrm{b}} \pm 0.02$ & $0.012^{\mathrm{a}} \pm 0.03$ \\
\hline $\mathrm{P}\left(\mathrm{mg} \mathrm{g}^{-1}\right)$ & $0.53^{\mathrm{c}} \pm 0.03$ & $0.72^{\mathrm{b}} \pm 0.02$ & $0.86^{\mathrm{b}} \pm 0.06$ & $1.00^{\mathrm{a}} \pm 0.09$ & $1.23^{\mathrm{a}} \pm 0.03$ \\
\hline $\mathrm{N}(\%)$ & $0.95^{\mathrm{c}} \pm 0.02$ & $1.74^{\mathrm{bc}} \pm 0.01$ & $2.13^{\mathrm{b}} \pm 0.04$ & $3.34^{\mathrm{b}} \pm 0.02$ & $6.52^{\mathrm{a}} \pm 0.03$ \\
\hline $\mathrm{K}\left(\mathrm{mg} \mathrm{g}^{-1}\right)$ & $0.002^{\mathrm{c}} \pm 0.01$ & $0.006^{\mathrm{c}} \pm 0.01$ & $0.008^{\mathrm{c}} \pm 0.01$ & $0.017^{\mathrm{b}} \pm 0.01$ & $0.068^{\mathrm{a}} \pm 0.02$ \\
\hline Organic carbon $(\%)$ & $2.60^{\mathrm{e}} \pm 0.03$ & $10.2^{\mathrm{d}} \pm 0.02$ & $16.3^{\mathrm{c}} \pm 0.01$ & $28.8^{\mathrm{b}} \pm 0.03$ & $74.4^{\mathrm{a}} \pm 0.02$ \\
\hline $\mathrm{C}: \mathrm{N}$ ratio & $2.74^{\mathrm{d}} \pm 0.03$ & $5.86^{\mathrm{c}} \pm 0.01$ & $7.65^{\mathrm{c}} \pm 0.03$ & $8.62^{\mathrm{b}} \pm 0.02$ & $11.44^{\mathrm{a}} \pm 0.02$ \\
\hline Bulk density $\left(\mathrm{g} \mathrm{cm}^{-3}\right)$ & $0.98^{\mathrm{a}} \pm 0.01$ & $0.87^{b} \pm 0.03$ & $0.83^{b} \pm 0.02$ & $0.77^{\mathrm{c}} \pm 0.01$ & $0.57^{\mathrm{d}} \pm 0.04$ \\
\hline
\end{tabular}

Source: Embrandiri (2016)

Superscript letters indicate the significant difference at $p>0.05$

decanter cake in agriculture, most especially with respect to plant growth. Notwithstanding, several studies have been reported to utilize organic wastes for the enhancement of plant growth. (Kelepsei et al. 2009; Ndaeyo et al. 2013; Adjei-Nsiah and Obeng 2013; Danaher and Pickens 2016; Kumar and Chopra 2016). Therefore, this work contributes to knowledge on the employment of decanter cake for the growth of vegetable plants in palm-producing countries. Although the wastes from the oil mills are expected to be organic in composition, there is unforeseen contamination of metals. This is as a result of leaks in the machinery or during washing process (Singh 2008). Due to the expected increase in oil palm acreage in the years ahead, it is eminent that serious measures have to be taken to ensure the proper management of decanter cake to address the growing environmental concerns. The aim of the present research was to investigate the uptake and accumulation of metal ions in the different plant parts from the soil and decanter cake amendments via the bioconcentration and translocation factors. The focus was on the transfer of nutrients and which parts have accumulated more metals than others and not on the potential of the plant to remediate the soil. It is generally found that when the BCF value is $\leq 1$, the plant can only absorb but not accumulate metals, but BCF value of $>1$ denotes that plant can accumulate metals.

\section{Methodology}

Decanter cake (DC) samples sourced from a mill in Penang, Malaysia, were dried and powdered and then sieved with a $2 \mathrm{~mm}$ mesh sieve. Soil samples used in the experiment were collected from a depth of $10 \mathrm{~cm}$ also from the vicinity of the mill. It was dried, homogenized and sieved $(2 \mathrm{~mm})$ according to standard protocol. The experiments consisted of $3 \mathrm{~kg}$ of DC-amended soils in planter pots $(15 \mathrm{~cm} \times 15 \mathrm{~cm})$ arranged in completely, randomized block design (CRBD). Amendments (0\% (control), 10, 20 and 30\% w/w DC) were mixed homogenously, filled into pots and left for 15 days stabilization (Singh 2008). The seeds of lady's finger, tomato and brinjal/eggplant were immersed in distilled water for $3 \mathrm{~min}$ prior to sowing to enhance germination. Ten seeds were sown manually at equidistant positions and seedlings were thinned to three plants per pot and kept in the nursery throughout the experiment.

For the analysis of metals in plant parts, all the samples were dried in the oven at $80{ }^{\circ} \mathrm{C}$. A fixed amount of the ground sample $(1 \mathrm{~g})$ was digested in $20 \mathrm{~mL}$ tri-acid mixture $\left(\mathrm{HNO}_{3}: \mathrm{H}_{2} \mathrm{SO}_{4}: \mathrm{HClO}_{4}\right.$ in the ratio 5:1:1) till a clear solution was obtained (Allen et al. 1986). The concentrations of metal ions were determined from the digested solution using the atomic absorption spectrophotometer (PerkinElmer Analyst 200 AAS 2007).

The uptake and distribution of metals in different plant parts were calculated from the translocation and bioconcentration factor values. To evaluate the plants' ability in transferring metals from the roots to the aerial parts, the translocation factor (TF) was calculated as shown in the formula below according to Mattina et al. (2003):

$$
\begin{aligned}
\mathrm{TF}= & \frac{\text { Concentration of metals in aerial parts at different treatments }}{\text { Concentration of metal in root }} \\
& \times 100 .
\end{aligned}
$$

The bioconcentration factor (BCF) was used to calculate the metal uptake capacity from soil to plant tissues, using the equation below (Zhao et al. 2003): 
Table 2 Bioconcentration factors of metals in leaves, shoots and fruits of lady's finger grown in different decanter cake amendments (mean $\pm \mathrm{SD}$ )
Table 3 Bioconcentration factors of metals in leaves, shoots and fruits of tomato grown at different decanter cake amendments (mean $\pm \mathrm{SD}$ )

\begin{tabular}{lcllll}
\hline Plant part & $\mathrm{DC}(\%)$ & $\mathrm{Cu}$ & $\mathrm{Ni}$ & $\mathrm{Zn}$ & $\mathrm{Mg}$ \\
\hline Leaf & 0 & $0.914^{\mathrm{a}} \pm 0.06$ & $0.266^{\mathrm{c}} \pm 0.02$ & $0.522^{\mathrm{b}} \pm 0.09$ & $0.010^{\mathrm{bc}} \pm 0.01$ \\
& 10 & $0.604^{\mathrm{b}} \pm 0.05$ & $0.473^{\mathrm{b}} \pm 0.03$ & $0.706^{\mathrm{b}} \pm 0.16$ & $0.030^{\mathrm{bc}} \pm 0.01$ \\
& 20 & $0.200^{\mathrm{c}} \pm 0.04$ & $0.418^{\mathrm{b}} \pm 0.02$ & $0.840^{\mathrm{a}} \pm 0.15$ & $0.020^{\mathrm{bc}} \pm 0.01$ \\
& 30 & $0.269^{\mathrm{c}} \pm 0.07$ & $0.371^{\mathrm{c}} \pm 0.01$ & $0.735^{\mathrm{a}} \pm 0.09$ & $0.020^{\mathrm{bc}} \pm 0.01$ \\
& 0 & $0.839^{\mathrm{a}} \pm 0.06$ & $0.501^{\mathrm{b}} \pm 0.01$ & $0.401^{\mathrm{c}} \pm 0.48$ & $0.010^{\mathrm{bc}} \pm 0.02$ \\
Shoot & 10 & $0.751^{\mathrm{a}} \pm 0.05$ & $0.327^{\mathrm{c}} \pm 0.01$ & $0.947^{\mathrm{a}} \pm 0.33$ & $0.020^{\mathrm{b}} \pm 0.01$ \\
& 20 & $0.560^{\mathrm{b}} \pm 0.06$ & $0.339^{\mathrm{c}} \pm 0.04$ & $0.640^{\mathrm{b}} \pm 0.16$ & $0.010^{\mathrm{a}} \pm 0.01$ \\
& 30 & $0.214^{\mathrm{c}} \pm 0.02$ & $0.302^{\mathrm{c}} \pm 0.01$ & $0.715^{\mathrm{b}} \pm 0.18$ & $0.010^{\mathrm{ab}} \pm 0.02$ \\
& 0 & $1.200^{\mathrm{a}} \pm 0.23$ & $0.520^{\mathrm{a}} \pm 0.03$ & $0.400^{\mathrm{c}} \pm 0.08$ & $0.010^{\mathrm{bc}} \pm 0.01$ \\
Fruit & 10 & $0.490^{\mathrm{c}} \pm 0.401$ & $0.511^{\mathrm{a}} \pm 0.05$ & $0.240^{\mathrm{d}} \pm 0.05$ & $0.030^{\mathrm{bc}} \pm 0.01$ \\
& 20 & $0.350^{\mathrm{c}} \pm 0.09$ & $0.501^{\mathrm{b}} \pm 0.30$ & $0.271^{\mathrm{d}} \pm 0.06$ & $0.050^{\mathrm{a}} \pm 0.04$ \\
& 30 & $0.696^{\mathrm{b}} \pm 0.19$ & $0.547^{\mathrm{a}} \pm 0.01$ & $0.280^{\mathrm{d}} \pm 0.03$ & $0.040^{\mathrm{a}} \pm 0.05$ \\
\hline
\end{tabular}

Mean values in the same column followed by the same superscript letters are not significantly different $(p>0.05)$

\begin{tabular}{lcrlrr}
\hline Plant part & DC $(\%)$ & \multicolumn{1}{l}{$\mathrm{Ni}$} & $\mathrm{Cu}$ & \multicolumn{1}{l}{$\mathrm{Zn}$} \\
\hline Leaf & 0 & $0.42^{\mathrm{ef}} \pm 0.01$ & $1.95^{\mathrm{a}} \pm 0.40$ & $2.14^{\mathrm{c}} \pm 0.26$ & $0.00^{\mathrm{ab}} \pm 0.01$ \\
& 10 & $0.46^{\mathrm{f}} \pm 0.02$ & $0.88^{\mathrm{a}} \pm 0.10$ & $0.80^{\mathrm{ab}} \pm 0.15$ & $0.02^{\mathrm{c}} \pm 0.02$ \\
& 20 & $0.34^{\mathrm{bcd}} \pm 0.01$ & $1.53^{\mathrm{a}} \pm 0.33$ & $0.67^{\mathrm{ab}} \pm 0.15$ & $0.01^{\mathrm{c}} \pm 0.01$ \\
& 30 & $0.41^{\mathrm{def}} \pm 0.02$ & $1.23^{\mathrm{a}} \pm 0.15$ & $0.87^{\mathrm{ab}} \pm 0.13$ & $0.01^{\mathrm{c}} \pm 0.02$ \\
& 0 & $0.34^{\mathrm{bcd}} \pm 0.03$ & $0.75^{\mathrm{a}} \pm 0.25$ & $1.83^{\mathrm{bc}} \pm 0.07$ & $0.01^{\mathrm{ab}} \pm 0.02$ \\
Shoot & 10 & $0.27^{\mathrm{ab}} \pm 0.01$ & $1.16^{\mathrm{a}} \pm 0.16$ & $0.80^{\mathrm{ab}} \pm 0.15$ & $0.01^{\mathrm{c}} \pm 0.01$ \\
& 20 & $0.30^{\mathrm{bc}} \pm 0.02$ & $0.57^{\mathrm{a}} \pm 0.15$ & $0.69^{\mathrm{ab}} \pm 0.16$ & $0.01^{\mathrm{c}} \pm 0.01$ \\
& 30 & $0.22^{\mathrm{a}} \pm 0.01$ & $0.29^{\mathrm{a}} \pm 0.03$ & $0.71^{\mathrm{ab}} \pm 0.11$ & $0.01^{\mathrm{ab}} \pm 0.03$ \\
& 0 & $0.35^{\mathrm{cde}} \pm 0.07$ & $3.58^{\mathrm{b}} \pm 0.72$ & $2.07^{\mathrm{c}} \pm 0.30$ & $0.01^{\mathrm{ab}} \pm 0.03$ \\
Fruit & 10 & $0.27^{\mathrm{ab}} \pm 0.11$ & $1.19^{\mathrm{b}} \pm 0.63$ & $0.85^{\mathrm{ab}} \pm 0.26$ & $0.01^{\mathrm{b}} \pm 0.01$ \\
& 20 & $0.30^{\mathrm{bc}} \pm 0.03$ & $0.48^{\mathrm{b}} \pm 0.08$ & $0.66^{\mathrm{ab}} \pm 0.38$ & $0.01^{\mathrm{ab}} \pm 0.02$ \\
& 30 & $0.23^{\mathrm{a}} \pm 0.03$ & $0.27^{\mathrm{b}} \pm 0.11$ & $0.54^{\mathrm{a}} \pm 0.17$ & $0.03^{\mathrm{a}} \pm 0.01$ \\
\hline
\end{tabular}

Mean values in the same column followed by the same superscript letters are not significantly different $(p>0.05)$
$\mathrm{BCF}=\frac{\text { Concentration of metals in plant parts }}{\text { Concentration of metal in test soil }}$.

\section{Statistical analysis}

The obtained data were subjected to one-way analysis of variance (ANOVA) using SPSS 16. Duncan's multiple range test (DMRT) was performed to test the significance of difference between the treatments at $p=0.05$.

\section{Results and discussion}

The accumulation of metals by plants generally depends on a number of factors including the physicochemical properties of the soil, the species planted, climatic conditions and chemical speciation of metals (Alloway et al. 1991; Greger 1999). The initial physiochemical characteristics are presented in Table 1 . The results of $\mathrm{BCF}$ revealed the highest level of $\mathrm{Zn}$ in the leaves of brinjal plants, which were grown in control soil $(2.37 \pm 0.26)$ as compared to other plants, whereas the $\mathrm{BCF}$ values of $\mathrm{Mg} \mathrm{BCF}$ in all three plants were found to be in very low range (0.01-0.05) (Tables $1,2,3)$. The bioconcentration factor of $\mathrm{Cu}$ was highest in the fruits of lady's finger grown in control $(3.58 \pm 0.72)$, while $\mathrm{BCF}$ of $\mathrm{Ni}$ was maximum in brinjal leaf at $10 \% \mathrm{DC}$ treatment $(0.66 \pm 0.02)$. This varying trend can be attributed to the chelation properties between the metals and amino acids (Odum et al. 2005). Kim et al. (2003) have accredited the difference in metal concentrations in various plant parts to compartmentalization and translocation through the vascular system. Plants could accrue and store metals in root and stem in nontoxic forms (Baker and Brooks 1989). 
Fig. 1 Bar graphs showing the translocation factors of $\mathrm{Cu}, \mathrm{Ni}$, $\mathrm{Mg}$ and, $\mathrm{Zn}$ of the leaves (L) and shoots (S) of lady's finger plants (mean $\pm \mathrm{SD}$ )
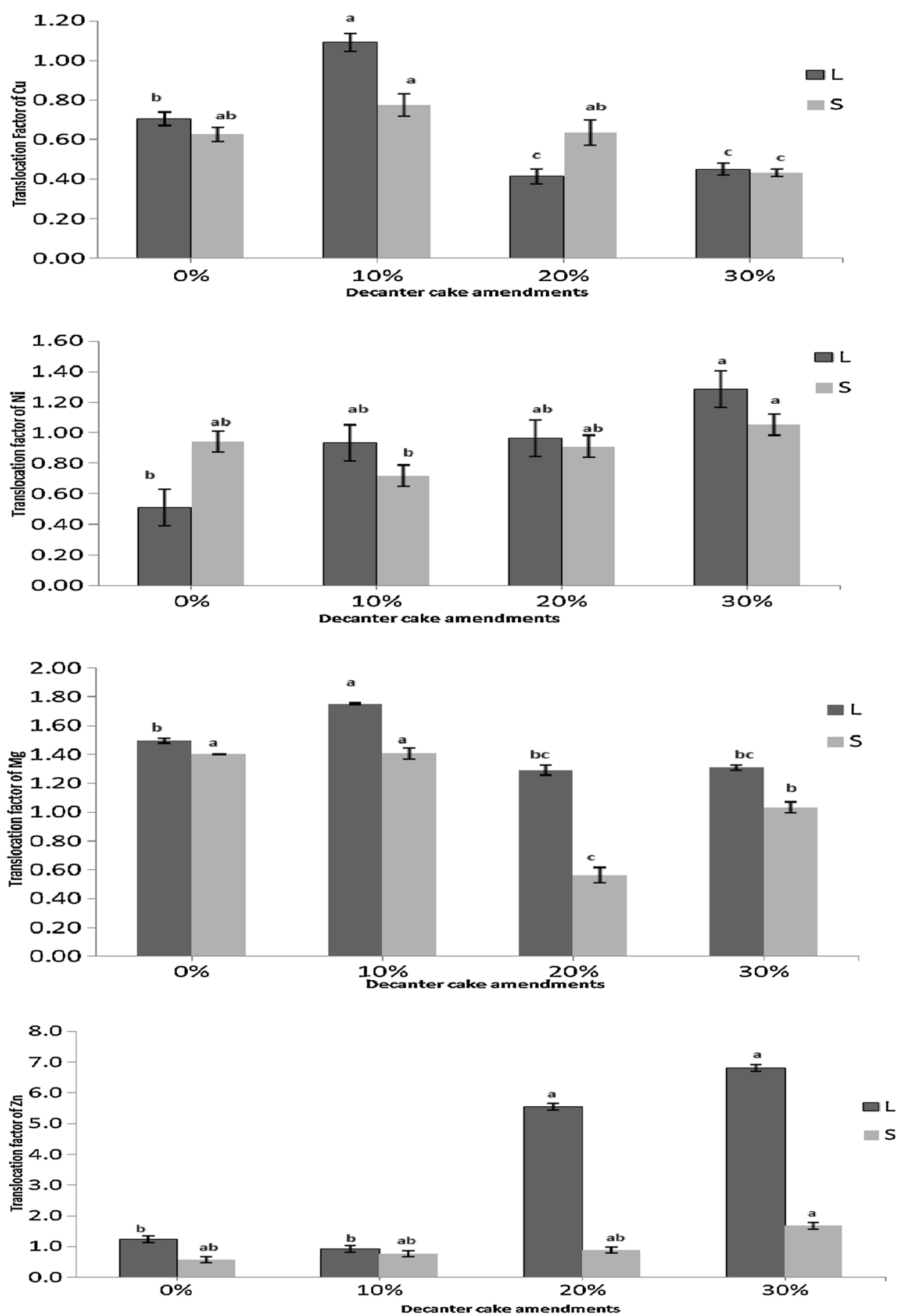

Lower BCF values indicate that the test plants showed difficulties to mobilize metals from the soil. The movement of metal ions from roots to shoots occurred due to speciation of elements, soil $\mathrm{pH}$ and soil organic matter (Kabata-Pendias and Pendias 1984). The wide variations in BCF values of heavy metals for sunflower, castor oil, alfalfa and mustard plants grown in hydroponic cultures were observed by Zhi-xin et al. (2007). The BCF values obtained for control and DC-amended plants were less than 1 (Tables 1, 2, 3). In tomato and brinjal plants, some BCF values were found to be above 1, which can also be considered safe for consumption as they do not exceed the recommended WHO limits.

The value of TF for all three plants was higher than control plants but with respect to individual metal ions and plant parts there were varying trends. TF value of $\mathrm{Zn}$ in the leaves of lady's finger plants was greater than 1 (Fig. 1), whereas in both shoots and leaves, translocation 
Fig. 2 Bar graphs showing the translocation factors of $\mathrm{Cu}, \mathrm{Ni}$, $\mathrm{Mg}$ and $\mathrm{Zn}$ of the leaf $(\mathrm{L})$ and shoot (S) portions of tomato plants (mean $\pm \mathrm{SD}$ )
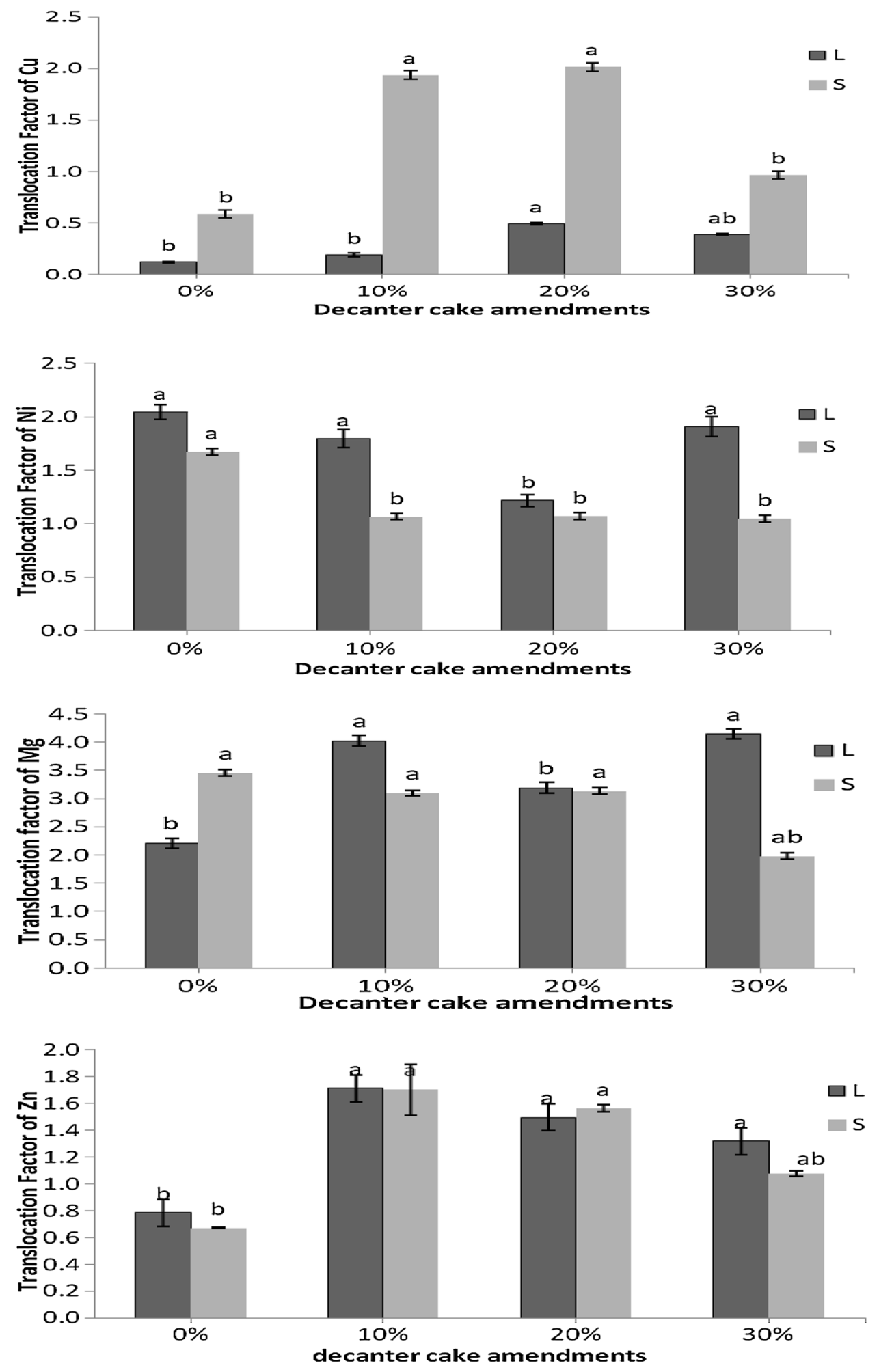

factor of $\mathrm{Ni}$ was higher in only $30 \%$ DC soil. In tomato plants, all treatments showed translocation factor of $\mathrm{Zn}$ greater than 1, except in control, whereas for translocation factor of $\mathrm{Mg}$ (Fig. 2) values were greater than 1 in root and shoot portions. For brinjal plants, Ni TF was higher than 1 in leaves and shoots (Fig. 3). This varying concentration of metals is due to the difference in assimilation rate and plant physiology (Singh et al. 2007, 2009, 2012). Even though tomato and brinjal belong to the same family, brinjal has a higher rate of 
Fig. 3 Bar graphs showing the translocation factors of $\mathrm{Cu}, \mathrm{Ni}$, $\mathrm{Mg}$ and $\mathrm{Zn}$ of the leaf $(\mathrm{L})$ and shoot (S) portions of brinjal plants (mean $\pm \mathrm{SD}$ )
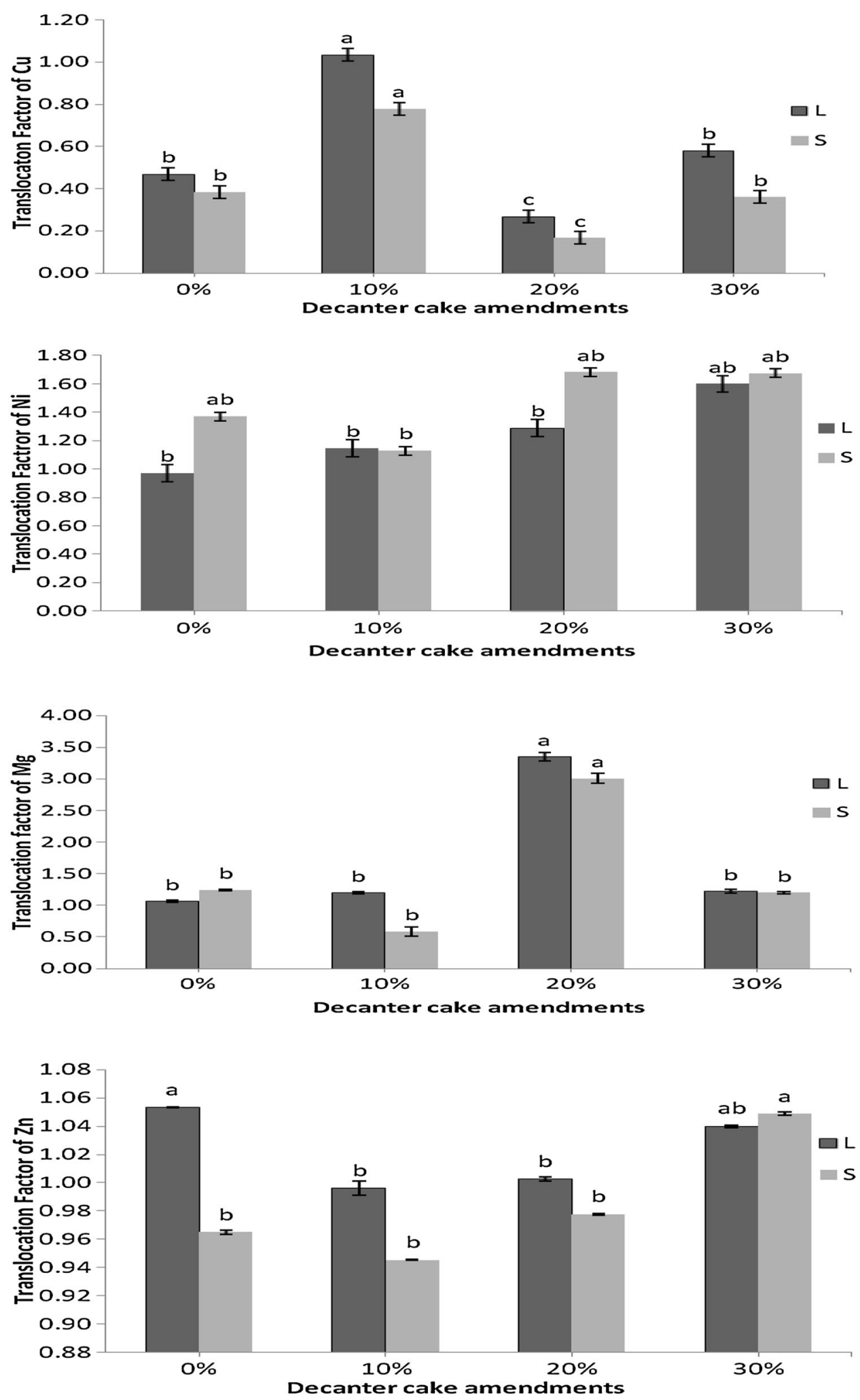

assimilation of nutrients while tomato and lady's finger do not. This is could be attributed to the different physiological mechanisms and graft incompatibility in solanaceous plants (Kawaguchi et al. 2008). In a similar study, the translocation factor of Fe for Jatropha curcas clones was higher in plants grown in the control soil than in the treatment plants (Ghavri and Singh 2010). Plants with both bioconcentration factor and translocation factor 


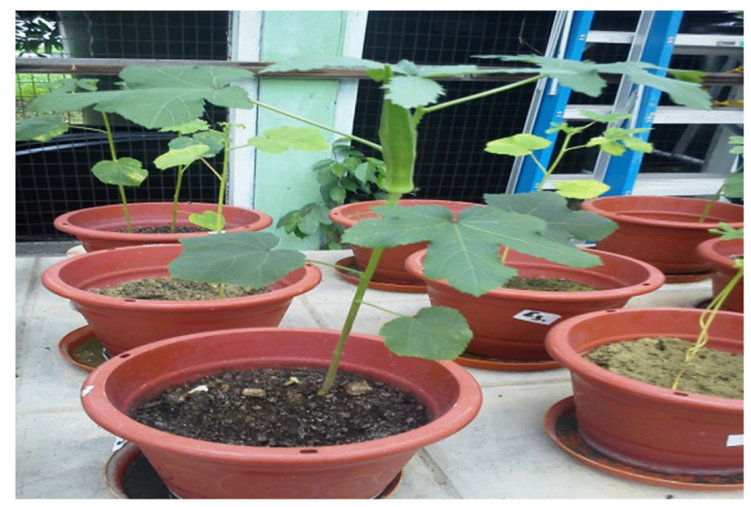

A

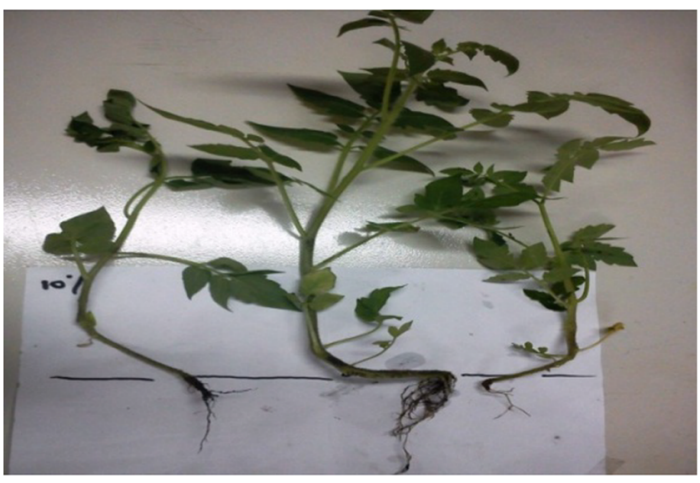

C

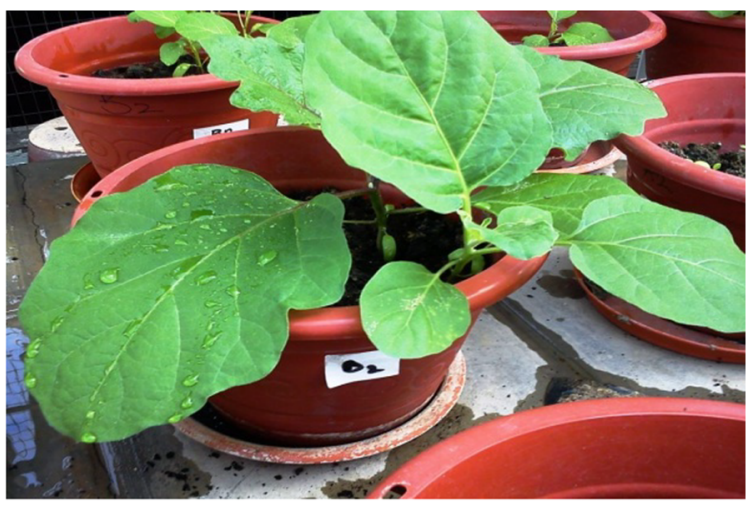

B

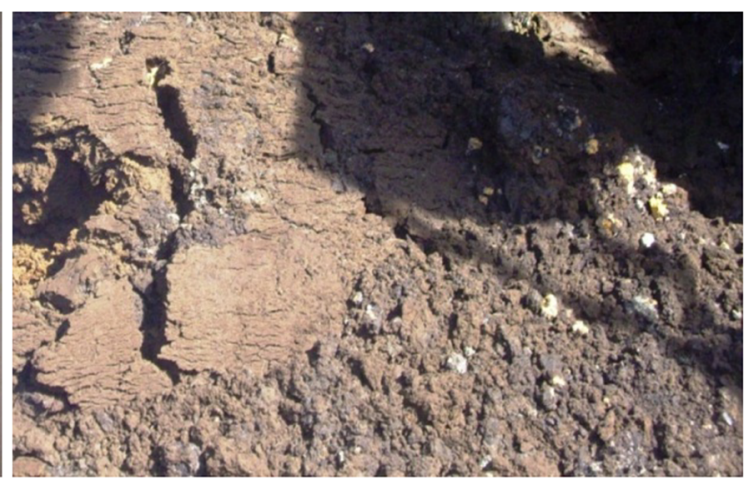

D

Fig. 4 Pictures during the experiment. a Lady's finger fruit in 10\% DC in soil. b Brinjal plant at 30\% DC in soil. c Tomato plants uprooted at $10 \%$ DC. d Fresh decanter cake

Table 4 Bioconcentration factors of metals in leaves, shoots and fruits of brinjal plants at different decanter cake amendments (mean $\pm \mathrm{SD}$ )

\begin{tabular}{lclrrr}
\hline Plant part & $\mathrm{DC}(\%)$ & $\mathrm{Cu}$ & \multicolumn{1}{l}{$\mathrm{Ni}$} & \multicolumn{1}{l}{$\mathrm{Mg}$} \\
\hline Leaf & 0 & $1.85^{\mathrm{a}} \pm 0.57$ & $0.62^{\mathrm{ef}} \pm 0.01$ & $2.37^{\mathrm{c}} \pm 0.26$ & $0.03^{\mathrm{ab}} \pm 0.01$ \\
& 10 & $0.78^{\mathrm{a}} \pm 0.10$ & $0.66^{\mathrm{f}} \pm 0.02$ & $0.73^{\mathrm{ab}} \pm 0.15$ & $0.05^{\mathrm{c}} \pm 0.02$ \\
& 20 & $1.43^{\mathrm{a}} \pm 0.33$ & $0.54^{\mathrm{bcd}} \pm 0.01$ & $0.58^{\mathrm{ab}} \pm 0.15$ & $0.02^{\mathrm{c}} \pm 0.02$ \\
& 30 & $1.13^{\mathrm{a}} \pm 0.15$ & $0.61^{\mathrm{def}} \pm 0.02$ & $0.72^{\mathrm{ab}} \pm 0.13$ & $0.02^{\mathrm{c}} \pm 0.01$ \\
& 0 & $0.85^{\mathrm{a}} \pm 0.54$ & $0.54^{\mathrm{bcd}} \pm 0.03$ & $1.74^{\mathrm{bc}} \pm 0.17$ & $0.02^{\mathrm{ab}} \pm 0.02$ \\
Shoot & 10 & $1.26^{\mathrm{a}} \pm 0.16$ & $0.47^{\mathrm{ab}} \pm 0.03$ & $0.60^{\mathrm{ab}} \pm 0.15$ & $0.03^{\mathrm{c}} \pm 0.03$ \\
& 20 & $0.67^{\mathrm{a}} \pm 0.15$ & $0.50^{\mathrm{bc}} \pm 0.02$ & $0.59^{\mathrm{ab}} \pm 0.16$ & $0.01^{\mathrm{c}} \pm 0.04$ \\
& 30 & $0.39^{\mathrm{a}} \pm 0.03$ & $0.42^{\mathrm{a}} \pm 0.01$ & $0.61^{\mathrm{ab}} \pm 0.11$ & $0.02^{\mathrm{ab}} \pm 0.03$ \\
& 0 & $2.37^{\mathrm{b}} \pm 0.72$ & $0.55^{\mathrm{cde}} \pm 0.07$ & $2.17^{\mathrm{c}} \pm 0.30$ & $0.04^{\mathrm{ab}} \pm 0.03$ \\
Fruit & 10 & $1.04^{\mathrm{a}} \pm 0.63$ & $0.47^{\mathrm{ab}} \pm 0.11$ & $0.95^{\mathrm{ab}} \pm 0.06$ & $0.02^{\mathrm{b}} \pm 0.01$ \\
& 20 & $0.38^{\mathrm{a}} \pm 0.08$ & $0.50^{\mathrm{bc}} \pm 0.03$ & $0.76^{\mathrm{ab}} \pm 0.38$ & $0.01^{\mathrm{ab}} \pm 0.02$ \\
& 30 & $0.17^{\mathrm{a}} \pm 0.11$ & $0.53^{\mathrm{a}} \pm 0.08$ & $0.64^{\mathrm{a}} \pm 0.07$ & $0.01^{\mathrm{a}} \pm 0.02$ \\
\hline
\end{tabular}

Mean values in the same column followed by the same superscript letters are not significantly different $(p>0.05)$ greater than 1 ( $\mathrm{TF}$ and $\mathrm{BCF}>1$ ) have the potential to be used in phytoextraction (Yoon et al. 2006). Therefore, based on data in this study, all three tested plants did not prove to have phytoextraction potential. On the other hand, Yoon et al. (2006) also noted that plants with bioconcentration factor greater than 1 and translocation factor less than $1(\mathrm{BCF}>1$ and $\mathrm{TF}<1)$ have the potential for phytostabilization (Fig. 3; Table 4). Figure 4 presents some of the pictures taken during the experiment. 


\section{Conclusions}

This study revealed that even though there was bioconcentration and translocation of metals such as $\mathrm{Ni}, \mathrm{Cu}, \mathrm{Mg}$ and $\mathrm{Zn}$ from the soil to plant parts, concentrations did not transfer to the fruit portions or exceed permissible FAO limits for vegetables. There is potential of lady's finger, tomato and brinjal to be used as phtyostabilizers with thorough investigations. Oil palm decanter cake compost amendments could therefore serve as a potential fertilizer source without the risk of metal accumulation and toxicity. Characterization of decanter cake and soil is necessary prior to pot application as metal mobility increases with lowering of $\mathrm{pH}$ and enhancement of organic carbon in the receptor soil. Decanter cake can function as an economical source of soil amendment to farmers particularly in Malaysia and other palm-producing nations. This would, over time, reduce the dependency on synthetic chemicals that have resulted in severe damages to flora and fauna communities and by extension to man.

Acknowledgements Authors are grateful to the Universiti Sains Malaysia RUI Grant (1001/PTEKIND/81124) for the financial assistance.

Open Access This article is distributed under the terms of the Creative Commons Attribution 4.0 International License (http://crea tivecommons.org/licenses/by/4.0/), which permits unrestricted use, distribution, and reproduction in any medium, provided you give appropriate credit to the original author(s) and the source, provide a link to the Creative Commons license, and indicate if changes were made.

\section{References}

Adam MA, Sulaiman A, Said MS, Som MA, Bahruddin AS, Mokhtar MN (2014) Preliminary study of oil palm decanter cake natural polymer composite (OPDC-NPC). Adv Mater Res 911:40-44

Adjei-Nsiah S, Obeng CB (2013) Effect of palm bunch ash application on soil and plant nutrient composition and growth and yield of garden eggs, pepper and okra. Int J Plant Soil Sci 2(1):1-15. doi:10.9734/IJPSS/2013/2039

Allen SE, Grim HM, Rowland AP (1986) Chemical analysis. In: Moore PD, Chapman SB (eds) Methods in plant ecology. Blackwell Scientific Publication, Oxford, pp 285-344

Alloway BJ, Jackson AP, Morgan H (1991) The behavior of heavy metals in sewage sludge amended soils. Sci Total Environ 100:151-176

Baker AJM, Brooks RR (1989) Terrestrial higher plants which hyper accumulate metallic elements: a review of their distribution, ecology and phytochemistry. Biorecovery 1:81-126

Danaher JJ, Pickens JM, Sibley JL (2016) Tomato seedling growth response to different water sources and a substrate partially replaced with dewatered aquaculture effluent. Int J Recycle Org Waste Agricult 5:25. doi:10.1007/s40093-016-0114-x

Embrandiri A, Ramli AA, Singh RP, Ibrahim MH (2012) Land application of biomass residue generated from palm oil processing: its potential benefits and threats. The Environmentalists 32(1):111-117
Embrandiri A, Singh RP, Ibrahim MH (2013) Biochemical, morphological and yield responses of Lady's finger plants to varying ratios of decanter cake application as a bio-fertilizer. Int $\mathbf{J}$ Recycle Org Waste Agricult (IJROWA) pp 2-7. doi:10.1186/ 2251-7715-2-7

Embrandiri A, Quaik S, Rupani PF, Srivastava V, Singh P (2015) Sustainable utilization of oil palm wastes: opportunities and challenges. In: RP Singh, Sarkar A (eds) In waste management: challenges, threats and opportunities, Nova Science Publishers, New York, pp 217-232

Embrandiri A (2016) Effects of oil palm decanter cake on growth of selected vegetables. $\mathrm{PhD}$ thesis, Universiti Sains Malaysia

Gafar AA, Alimon AR, Sazili AQ, Man YC, Abubakar AR (2013) Effect of varying levels of palm oil decanter cake on feed intake, growth performance and carcass characteristics of Kacang goats. IOSR J Agricult Vet Sci (IOSR-JAVS) 3(4):24-29

Ghavri SV, Singh RP (2010) Phytotranslocation of Fe by biodiesel plant Jatropha curcas L. grown on iron rich wasteland soil. $\mathrm{Br}$ Soc Plant Physiol 22(4):235-243

Greger M (1999) Metal availability and bioconcentration in plants. In: Prasad MNV, Hagemeyer J (eds) Heavy metal stress in plantsfrom molecules to ecosystems. Springer, Berlin, pp 1-27

Haron K, Mohammed AT (2008) Efficient use of inorganic and organic fertilisers for oil palm and potential utilisation of decanter cake and boiler ash for biofertiliser production. National Seminar on Biofertiliser. Biogas and Effluent Treatment in the Oil Palm Industry, Pp, pp 21-32

Kabata-Pendias A, Pendias H (1984) Trace elements in soils and plants, 4th edn. CRC Press, Boca Raton, FL. 85:107-129

Kawaguchi M, Taji A, Backhouse D, Oda M (2008) Anatomy and physiology of graft incompatibility in solanaceous plants. J Hortic Sci Biotechnol 83(5):581-588

Kelepsei S, Tzortzakis NG (2009) Olive mill wastes: a growing medium component for seedling and crop Production of lettuce and chicory. Int J Veg Sci 15:325-329. doi:10.1080/14620316. 2008.11512427

Kim IS, Kang HK, Johnson-Green P, Lee EJ (2003) Investigation of heavy metal accumulation in Polygonum thunbergii for phytoextraction. Environ Pollut 126:235-243

Kumar V, Chopra AK (2016) Effects of sugarcane pressmud on agronomical characteristics of hybrid cultivar of eggplant (Solanum melongena L.) under field conditions. Int J Recycle Org Waste Agricult 5:149. doi:10.1007/s40093-016-0125-7

Liew WL, Kassim MA, Muda K, Loh SK, Affam AC (2015) Conventional methods and emerging wastewater polishing technologies for palm oil mill effluent treatment: a review. J Environ Manag 149:222-235. doi:10.1016/j.jenvman.2014.10. 016

Mattina MJI, Lannucci-Berger W, Musante C, White JC (2003) Concurrent plant uptake of heavy metals and persistent organic pollutants from soil. Environ Pollut 124:375-378

Ndaeyo NU, IkehAO NK, Akpan EA, Udoh EI (2013) Growth and foliar yield responses of waterleaf (Talinum triangulare Jacq) to complementary application of organic and inorganic fertilizers in a ultisol. Am J Exp Agricult 3(2):324-335. doi:10.9734/AJEA/ 2013/2599

Odum E, Barret P, Gary W (2005) Fundamentals of ecology, 5th edn. Thomson Brooks/Cole, London

Razak MNA, Ibrahim MF, Yee PL, Hassan MA, Aziz SA (2012) Utilization of oil palm decanter cake for cellulase and polyoses production. Biotechnol Bioprocess Eng 17:547-555

Singh RP (2008) Land application of sewage sludge: appraisal of potential effects on plants. PhD Dissertation, Banaras Hindu University 
Singh RP, Agrawal M (2007) Effects of sewage sludge amendment on heavy metal accumulation and consequent responses of Beta vulgaris plants. Chemosphere 67:2229-2240

Singh RP, Agrawal M (2009) Use of sewage sludge as fertilizer supplement for Abelmoschus esculentus plants: physiological, biochemical and growth responses. Int J Environ Waste Manag 3:91-106

Singh P, Sulaiman O, Hashim R, Peng LC, Singh RP (2012) Using biomass residues from oil palm industry as a raw material for pulp and paper industry: potential benefits and threat to the environment. Environ Dev Sustain 12(2):1-17
Yoon J, Cao X, Zhou Q, Ma LQ (2006) Accumulation of Pb, Cu, and $\mathrm{Zn}$ in native plants growing on a contaminated Florida site. Sci Total Environ 368:456-464

Zhao FJ, Lombi E, McGrath SP (2003) Assessing the potential for zinc and cadmium phytoremediation with the hyperaccumulator Thlaspi caerulescens. Plant Soil 249(1):37-43

Zhi-Xin N, Li-Na S, Tie-Heng S, Yu-Shuang L, Hing W (2007) Evaluation of phytoextracting cadmium and lead by sunflower, ricinus, alfalfa and mustard in hydroponic culture. J Environ Sci 19:961-967 